Araştırma

Journal of Social Research and Behavioral Sciences

Sosyal Araştırmalar ve Davranış Bilimleri Dergisi

ISSN:2149-178X

Volume: 7 Issue: 13 Year: 2021

\title{
Which Factors Affect Pomegranate Production in Kandahar? An implementation of the Cobb-Douglas Production Function
}

\author{
Associate Prof. Mohammad Hasham Daqiq \\ Lecturer at Economic Faculty of Kandahar University \\ $\mathrm{PhD}$ Candidate Capital University of Economics and Business, Beijing \\ Kandahar-un@mohe.gov.af, Daqiq.hasham@gmail.com
}

\begin{abstract}
Pomegranates are one of the most important fruits in Kandahar province, which is famous for its pomegranates around the world. Pomegranates play a vital role in the socio-economic life of those who grow them. This study empirically analyzed the factors affecting pomegranate production in Kandahar province in Afghanistan. The study used primary data collected from 200 pomegranate growers in Dand, Panjwai and Daman districts of Kandahar province. These growers were selected using a random sampling method and the data was collected using a structured, pre-tested questionnaire.

An ordinary least squares regression model, based on an extended Cobb-Douglas production function, was used to analyze the data. The farmers' periodic income per hectare was used as a monetary measure of pomegranate production and was defined as the dependent variable. The explanatory variables considered for the study were average cost of fertilizer per hectare, average cost of urea per hectare, average cost of DAP per hectare, average cost of land preparation per hectare, average cost of chemicals per hectare, average cost of labor per hectare, and average cost of water supply per hectare. The results of the analysis show that of these seven independent variables, number female household members, average cost of DAP, average cost of urea, and average cost of water supply are significant at the $\mathrm{p}<0.01$ level, and the rest of the listed variables are insignificant at the $\mathrm{p}<0.05$ level. Furthermore, the $\mathrm{R}^{2}$ value of the model $(26 \%)$ suggests that there are other factors not included in the model which can influence pomegranate production.

In order to enhance the productivity of pomegranate production in Kandahar province, the government should provide farmers with assistance so that they can control those factors which affect the productivity of the fruit.
\end{abstract}

Keyword list: production, labor, cost, profit margin, farmers 


\section{Description of Data}

The study used primary data collected from pomegranate growers in three major districts of Kandahar province, Daman, Dand, and Arghandab. These districts are the largest and most famous producers of pomegranates in the province. The number of samples collected for the study was 200 pomegranate growers. The survey method used to collect the necessary cross-sectional primary data is widely used in the field of social science. The data was collected with the help of a pre-tested, structured questionnaire which contained questions relating to size of land, cropping pattern, input costs, labor costs, transportation, processing costs, selling prices, profit margins, etc.

The steps which enabled us to reach to our target audience are described below.

- Daman, Dand, and Arghandab districts were selected by considering their high level of pomegranate production.

- Daman has a total population of 35,402, Dand 45,842, and Arghandab 63,243. In total, they have a combined population of 144,487 .

- By considering the populations of each district and their proportion of the combined population of the three districts, the percentage of the samples to be collected from each district was determined as Daman 24.5\%, Dand 31.7\%, and Arghandab 43.7\%.

- The 200 samples were distributed according to these proportions, giving 88 samples for Arghandab, 63 for Dand and 49 for Daman.

- A list of farmers was prepared based on the areas with pomegranate gardens.

- Among the listed farmers, random sampling was used to choose farmers for interview.

\section{Research Question/Theoretical Contextualization}

Pomegranate production is an important contributor to the Afghan economy. Pomegranates are considered a major fruit crop or the main source of livelihood for thousands of Afghans in many provinces, e.g. Helmand, Ghazni, Farha, Paktia, Kapisa, Wardak and Balkh. However, the world's 
best pomegranates are produced in the desert region of Kandahar, where the muted brown of Kandahar turns into lush green blended with shades of red, with rows of pomegranate trees full of hanging fruits. Afghanistan is known as the country of the pomegranate fruit, not only because of its conventional production methods, but also because of the high quality of the landraces grown there (Dawrani, 2013).

Since 2009, the government and NGOs have increased their focus on the development of the pomegranate industry in Afghanistan. In 2009, several hundred thousand pomegranate trees were planted, and the nation exported nearly 50,000 tonnes of the fruit to different countries such as Pakistan and India. Also in 2009, an almost six million pound juice factory was constructed in Kabul to make the more commercially viable juice concentrate from the fruit (Sadiq, 2010). Furthermore, the Afghan government helped the industry by promoting fruit exports. Assistance was also provided by the US Agency for International Development, which launched the \$6.6 million Kandahar Orchard Project to offer farmers credit to plant new pomegranate trees, particularly on former poppy land (Dawrani, 2010).

The year 2015 was a successful year for Kandahar pomegranates, and according to the report of the Kandahar Chamber of Commerce (KCC), 7,681 tonnes of pomegranates have been exported from Kandahar to different countries, including Pakistan, Tajikistan, India, and even Europe (KCC, 2015).

Recent data published by the Afghanistan Central Statistic Organization (CSO) in 2017 shows that a total of 99,871 tonnes of pomegranates were produced in Afghanistan on 9,721 hectares of land. Of this, Kandahar produced 72,100 tonnes of pomegranates on 4,825 hectares of land (CSO, 2017). Furthermore, according to a report by Pajhwok published in November 2018, Kandahar province produced 150,000 tonnes of pomegranates on 8,000 hectares of land, of this only 18,000 tonnes were exported to other countries. These exported pomegranates were worth of four million USD (Pajhwok, 2018).

In the last few years there have been some major changes to the farming system of Kandahar. Farmers have shifted towards multiple cropping and new profitable crops have been introduced. These changes were precipitated by the knowledge brought by Afghans returning from Pakistan and the recent input and support from different international organizations (afghanag.ucdavis.edu, 2019). 
Pomegranate production in Afghanistan seems to be a great success, and the industry has great potential for increased production. However, there is little investment in the sector. The reason for this lack of investment in the industry is the information gap caused by the fact that most Afghan traders and farmers do not have enough information about the production of their products to know where to invest and how they can improve their production process. Among the provinces of Afghanistan, Kandahar produces the most and the highest quality pomegranates. Although the province has the potential for increased production, nobody knows which factors would be effective at increasing production. By considering the information gap regarding pomegranate production in the province, this study was designed to follow the production of pomegranates and analyze the factors which influence its production. This study is specifically designed to help Afghan farmers, investors, the government and other stakeholders to better understand the production process and which factors can influence the production.

Specifically, the study seeks to answer the following important questions:

- What are the main factors affecting the pomegranate production in Kandahar province?

- How profitable is pomegranate production for farmers?

- What policies could be recommended to stakeholders to effectively promote pomegranate production in Kandahar?

\section{Field Research Design/ Methods of Data Analysis}

The main objective of this study is to determine the pomegranate input - output relationship using a mathematical function in order to better understand the influence of different inputs on pomegranate output. The Cobb-Douglas production function is the method or function recommended by most of the literature. It is specifically designed to represent the technological relationship between two or more inputs and an output. The function is theoretically presented in the following form: 


$$
\operatorname{Output}(\mathrm{Y})=\mathrm{A} \mathrm{L}^{\beta} \mathrm{K}^{\alpha}
$$

In the above function,

- $\mathrm{Y}=$ total production,

- $\mathrm{A}=$ total factor productivity,

- $\quad \mathrm{L}=$ labor input,

- $\quad \mathrm{K}$ = capital input

- $\quad \beta, \alpha=$ the output elasticities of the inputs labor and capital.

To develop the basic function into its stochastic type, the function is changed to the following form:

$$
Y=\beta_{0} X_{1 i}^{\beta 1 \mathrm{i}} X_{2 i}^{\beta 2 \mathrm{i}} e^{u i}
$$

In the above function,

- $\quad \mathrm{Y}=$ output,

- $\quad X_{1}=$ labor input,

- $\mathrm{X}_{2}=$ capital input,

- $\quad \mathrm{u}=$ stochastic disturbance term,

- $\quad \mathrm{e}=$ base of natural logarithm.

In the above Cobb-Douglas production function the relationship between inputs and output are non-linear. Therefore, several researchers have made the parameters linear, e.g. Gugrati, 2003. In order to make the parameters linear we can take the log of the variables, resulting in a log-linear model.

$$
\ln Y=\ln \beta_{0}+\beta_{1} \ln X_{1}+\beta_{2} \ln X_{2}+u_{i}
$$

In the above function the variables are still non-linear, but taking the log of the parameters makes the model linear, and it can therefore be easily analyzed using a linear OLS regression model.

To use the Cobb-Douglas production function for this case study, we had to extend the above model by adding all the inputs used in the production of pomegranates. The extended model of the Cobb-Douglas production function is:

$$
\ln Y=\beta_{0}+\beta_{1} X_{1}+\beta_{2} X_{2}+\beta_{3} X_{3}+\beta_{4} X_{4}+\beta_{5} X_{5}+\beta_{6} X_{6}+\beta_{7} X_{7}+u_{i}
$$


In the above function,

- $\quad \ln =$ natural logarithm,

- $\mathrm{Y}=$ net periodic earnings/hectare,

- $\beta_{0}=$ intercept,

- $\mathrm{X}_{1}=$ cost of urea per hectare,

- $\mathrm{X}_{2}=$ cost of DAP/hectare,

- $\quad X_{3}=$ cost of fertilizers/hectare,

- $\mathrm{X}_{4}=$ cost of land preparation/hectare,

- $\quad \mathrm{X}_{5}=$ cost of labor/hectare,

- $\mathrm{X}_{6}=$ cost of watering,

- $\mathrm{X}_{7}=$ cost of chemicals/hectare,

- $\quad \mathrm{u}_{\mathrm{i}}=$ stochastic disturbance term

- $\quad \beta_{0}$------------- $\beta_{7}=$ coefficients of respective variable.

\section{Results}

As mentioned in the data analysis section, the study used primary data collected from three district of Kandahar province. Before presenting the empirical regression, we describe some qualitative statistics of the target population using a few tables.

Table 1: Household Heads' Education

\begin{tabular}{|c|c|c|c|c|c|}
\multicolumn{1}{|c|}{$\begin{array}{c}\text { Years of } \\
\text { Education }\end{array}$} & Frequency & Percentage & Valid Percentage & $\begin{array}{c}\text { Cumulative } \\
\text { Percentage }\end{array}$ \\
\hline & 0 & 109 & 54.5 & 54.5 & 54.5 \\
\hline \multirow{3}{*}{ Valid } & 2 & 1 & 0.5 & 0.5 & 55.0 \\
\hline & 3 & 1 & 0.5 & 0.5 & 55.5 \\
\hline & 4 & 2 & 1.0 & 1.0 & 56.5 \\
\hline & 5 & 2 & 1.0 & 1.0 & 57.5 \\
\hline & 6 & 3 & 1.5 & 1.5 & 59.0 \\
\hline
\end{tabular}




\begin{tabular}{|c|c|c|c|c|c|}
\hline & 7 & 7 & 3.5 & 3.5 & 62.5 \\
\hline & 8 & 6 & 3.0 & 3.0 & 65.5 \\
\hline & 9 & 16 & 8.0 & 8.0 & 73.5 \\
\hline 10 & 15 & 7.5 & 7.5 & 81.0 \\
\hline & 11 & 3 & 1.5 & 1.5 & 82.5 \\
\hline & 12 & 25 & 12.5 & 12.5 & 95.0 \\
\hline & 14 & 4 & 2.0 & 2.0 & 97.0 \\
\hline & 15 & 2 & 1.0 & 1.0 & 100.0 \\
\hline
\end{tabular}

In Table1, it is noticeable that 109 of the household heads were illiterate, and only 35 individuals had high school level of education or above. The illiteracy level among the household heads was $54.5 \%$, which is a good sign.

\section{Table 2: Land Ownership Status}

\begin{tabular}{|c|l|c|c|c|c|}
\hline \multicolumn{2}{|c|}{} & Frequency & Percentage & $\begin{array}{c}\text { Valid } \\
\text { Percentage }\end{array}$ & $\begin{array}{c}\text { Cumulative } \\
\text { Percentage }\end{array}$ \\
\hline \multirow{3}{*}{ Valid } & Not own & 4 & 2.0 & 2.0 & 2.0 \\
\cline { 2 - 6 } & land & & & & 100.0 \\
\cline { 2 - 7 } & Own land & 196 & 98.0 & 98.0 & \\
\cline { 2 - 6 } & Total & 200 & 100.0 & 100.0 & \\
\hline
\end{tabular}

Table 2 shows the ownership status of the pomegranate fields. It shows whether the pomegranate growers were renting the pomegranate gardens, or whether they own the gardens they farm. The results show that out of 200 gardens only 4 were owned by someone other than the grower, who was paying rent. However, the other 196 gardens were owned by the growers. 


\begin{tabular}{|c|c|c|c|c|c|}
\hline & & Frequency & Percentage & $\begin{array}{c}\text { Valid } \\
\text { Percentage }\end{array}$ & $\begin{array}{l}\text { Cumulative } \\
\text { Percentage }\end{array}$ \\
\hline \multirow{7}{*}{ Valid } & 1 & 23 & 11.5 & 11.6 & 11.6 \\
\hline & 2 & 78 & 39.0 & 39.4 & 51.0 \\
\hline & 3 & 51 & 25.5 & 25.8 & 76.8 \\
\hline & 4 & 32 & 16.0 & 16.2 & 92.9 \\
\hline & 5 & 11 & 5.5 & 5.6 & 98.5 \\
\hline & 6 & 3 & 1.5 & 1.5 & 100.0 \\
\hline & Total & 198 & 99.0 & 100.0 & \\
\hline Missing & System & 2 & 1.0 & & \\
\hline \multicolumn{2}{|l|}{ Total } & 200 & 100.0 & & \\
\hline
\end{tabular}

The above Table 3 shows the number of workers working on a daily basis in the pomegranate gardens. The most common number of laborers working in a garden is three to four. Fifty-one pomegranate gardens had three people working daily, and 32 gardens had four laborers. Only 23 of the 200 gardens had just one laborer. It is important to mention that the number of laborers was partially connected to the size of the garden.

\section{Result of the regression}

After considering the type of data and reviewing information about pomegranate production in the available literature, we decided to carry out an OLS regression analysis using SPSS. The dependent variable was defined as the seasonal, periodic income of the farmers per hectare. The explanatory variables considered were average cost of fertilizer per hectare, average cost of urea per hectare, average cost of DAP per hectare, average cost of land preparation per hectare, average cost of chemicals per hectare, average cost of labor per hectare, and average cost of water supply per hectare. We took the natural logarithm of the variables, as this can make highly skewed distributions less skewed. It can also make patterns in the data easier to interpret and help make the data meet the assumptions of the inferential statistics used in the model. The regression gave the following results: 
Table 4: Model Summary ${ }^{\mathrm{b}}$

\begin{tabular}{|l|c|c|c|c|}
\hline Model & R & R Square & $\begin{array}{c}\text { Adjusted R } \\
\text { Square }\end{array}$ & Std. Error of the Estimate \\
\hline $\mathbf{1}$ & $0.517^{\mathrm{a}}$ & 0.268 & 0.230 & 0.73252 \\
\hline
\end{tabular}

a. Predictors: (constant), cost of water supply per hectare, number of male HH members, cost of DAP per hectare, cost of urea per hectare, cost of labor per hectare, cost of fertilizer per hectare, cost of land preparation per hectare, number of female $\mathrm{HH}$ members, cost of chemicals per hectare

\section{b. Dependent variable: $\ln ($ income)}

Table 4 shows the model summery, which indicates how much changes in the farmers' income can be explained by changes in the independent variables like average cost of fertilizer per hectare, average cost of urea per hectare, average cost of DAP per hectare, average cost of land preparation per hectare, average cost of chemicals per hectare, average cost of labor per hectare, and average cost of water supply per hectare. The value of $\mathrm{R}^{2}$ shows that almost $26 \%$ of the variance or changes in the farmers' income from pomegranate production is caused by the independent variables. However, $74 \%$ of changes in the farmers' income is caused by other factors which are not included in our model. The value of $\mathrm{R}^{2}$ is not as high as expected because there are a large number of other variables which influence farmers' income directly, e.g. number of trees in the garden, water system type, age of the plants, changes in temperature, etc. Other studies should focus on other factors influencing the growth of the plant, but this study only aims to specify which factors can increase the production of pomegranates, which will ultimately increase the incomes of the growers.

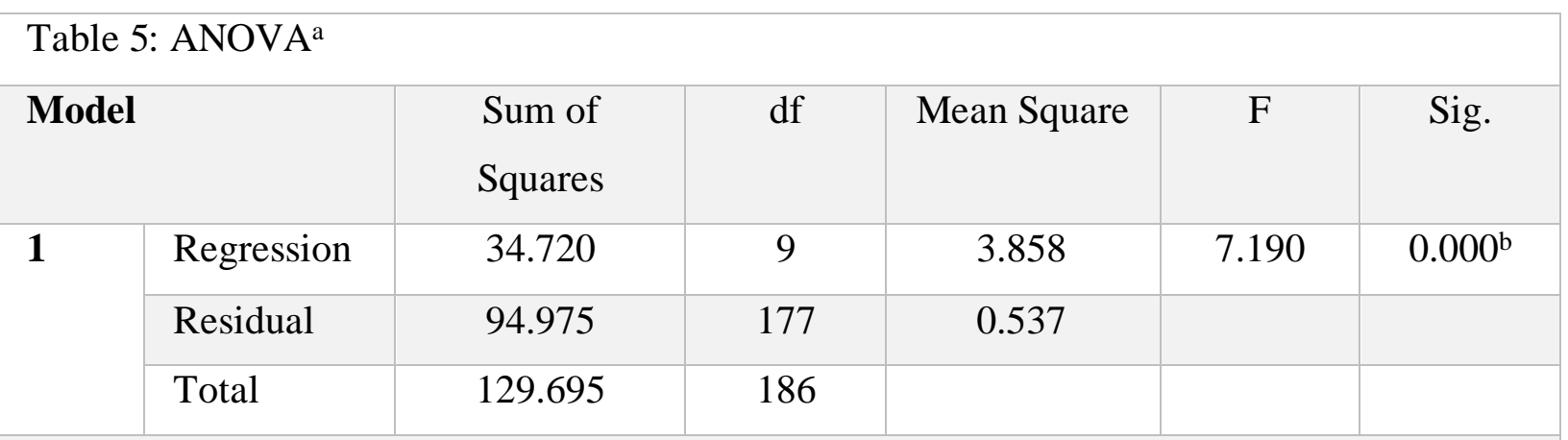

a. Dependent variable: $\ln ($ income per hectare) 


\section{b. Predictors: (constant), cost of water supply per hectare, number of male HH members, cost of DAP per hectare, cost of urea per hectare, cost of labor per hectare, cost of fertilizer per hectare, cost of land preparation per hectare, number of female HH members, cost of chemicals per hectare}

We conducted an ANOVA test to see how efficiently the model explains the dependent variable. The results of the ANOVA test, given in Table 5, show that the regression model predicts the dependent variable, the farmers' income per hectare from growing pomegranates, significantly well. An F value of 7.1 and a $p$-value of $p<0.000$, which is less than 0.05 , indicate that overall the regression model is statistically significant, that it predicts the outcome variables well, and that it is a good fit for the data.

Table 6: Coefficients ${ }^{\mathrm{a}}$

\begin{tabular}{|c|c|c|c|c|c|c|c|c|}
\hline & \multirow[t]{2}{*}{ Model } & \multicolumn{2}{|c|}{$\begin{array}{l}\text { Unstandardized } \\
\text { Coefficients }\end{array}$} & \multirow[t]{2}{*}{$\begin{array}{l}\text { Standardized } \\
\text { Coefficients }\end{array}$} & \multirow[t]{2}{*}{$t$} & \multirow[t]{2}{*}{ Sig. } & \multicolumn{2}{|c|}{$\begin{array}{c}95.0 \% \\
\text { Confidence } \\
\text { Interval for B }\end{array}$} \\
\hline & & B & $\begin{array}{l}\text { Std. } \\
\text { Error }\end{array}$ & & & & $\begin{array}{l}\text { Lower } \\
\text { Bound }\end{array}$ & $\begin{array}{l}\text { Upper } \\
\text { Bound }\end{array}$ \\
\hline \multirow[t]{4}{*}{1} & (Constant) & 9.879 & 0.223 & & 44.271 & 0.000 & 9.438 & 10.319 \\
\hline & $\begin{array}{l}\text { Number of } \\
\text { male HH } \\
\text { members }\end{array}$ & 0.017 & 0.020 & 0.062 & 0.813 & 0.417 & -0.024 & 0.057 \\
\hline & $\begin{array}{l}\text { Number of } \\
\text { female } \mathrm{HH} \\
\text { members }\end{array}$ & -0.044 & 0.016 & -0.224 & -2.845 & 0.005 & -0.075 & -0.014 \\
\hline & $\begin{array}{l}\text { Average } \\
\text { cost of } \\
\text { fertilizer } \\
\text { per hectare }\end{array}$ & $\begin{array}{c}6.745 \mathrm{E}- \\
005\end{array}$ & 0.000 & 0.061 & 0.827 & 0.409 & 0.000 & 0.000 \\
\hline
\end{tabular}




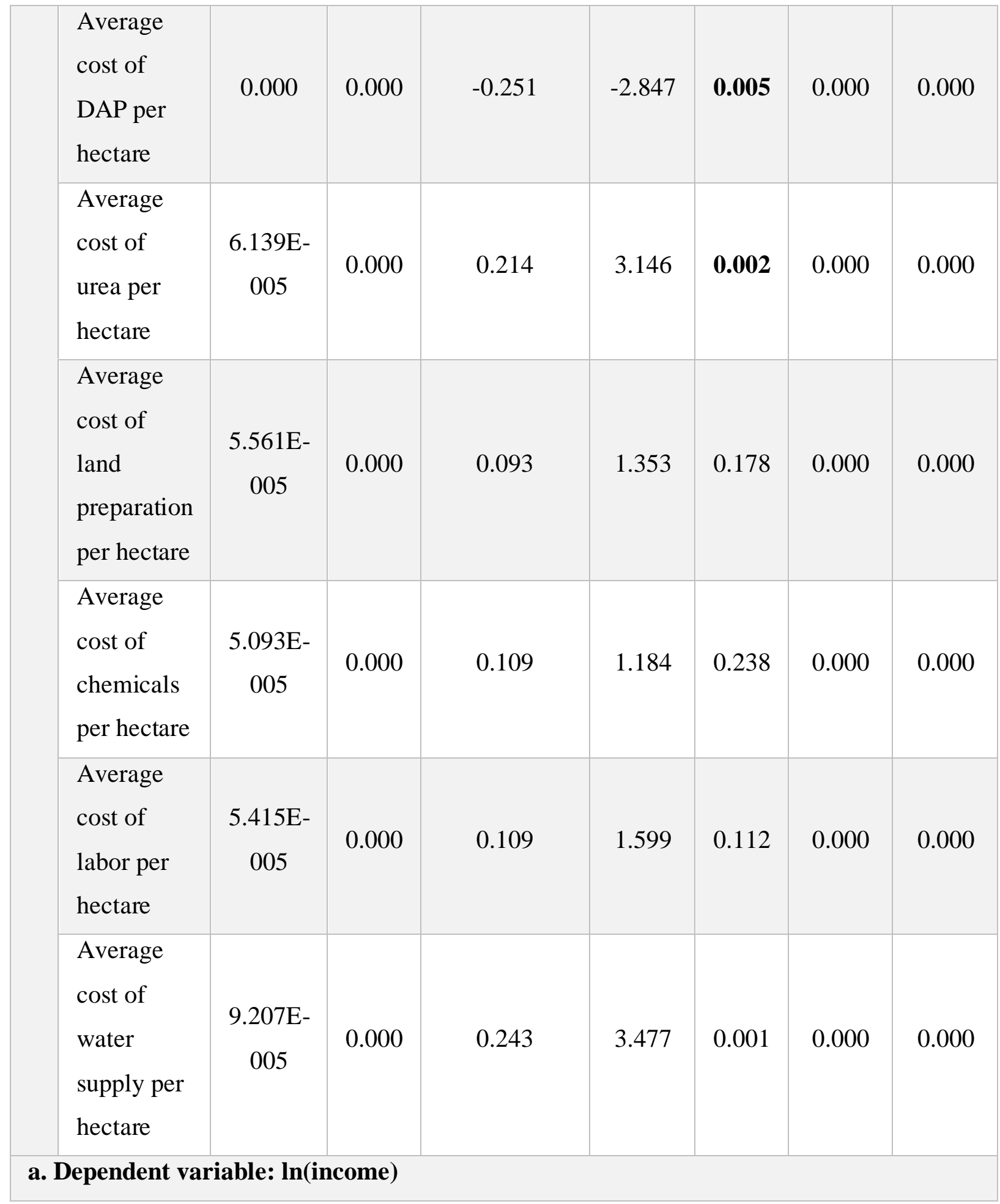

Looking at the beta values in the above table of coefficients, we can see that farmers' income is positively correlated with almost all the independent variables, including cost of fertilizer, cost of urea, cost of DAP, cost of land preparation, cost of chemicals, cost of labor, and cost of water 
supply. However, farmers' income is negatively correlated with the number of female household members. As most of the farmers hire their family members to work in their gardens, we included this variable (number of female HH members) in the model to see whether having more female than male family members affects the pomegranate production.

Among the explanatory variables, number of female household members, average cost of DAP, average cost of urea, and average cost of water supply are significant at the $\mathrm{p}<0.01$ level. The rest of the variables have p-values $>0.05$ and are therefore insignificant at the 5\% significance level. The positive sign of the significant coefficients means that increasing the cost of these variables will aid the growth of pomegranates and lead to an increase in the income of the grower. Furthermore, a negative coefficient of the number of female household members means that as the number of female members in the family of a pomegranate grower increases, pomegranate growth decreases.

Other factors, e.g. family size, type of urea, number of trees, size of land, etc. were considered in the analysis. However, after checking correlations among the variables, we removed those factors which were correlated with our main variables.

\section{Discussion and Conclusion}

This study aimed to analyze the factors affecting pomegranate production in Kandahar province. Data were collected from 200 pomegranate growers in Dand, Panjwai and Daman districts of Kandahar province during the period 2019. The study showed that cost of fertilizer, cost of urea, cost of DAP, cost of land preparation, cost of chemicals, cost of labor, and cost of water supply have a positive impact on pomegranate growing. However, farmers' income is negatively correlated with the number of female members in their household.

To examine technical efficiency, we used the extended Cobb-Douglas production function. The coefficient of multiple determination R squared was $26.8 \%$, and the adjusted R squared was $23 \%$. The F-value was 7.1 and this was highly significant at the $1 \%$ significance level.

Among the independent variables analyzed, only number of female household members, average cost of DAP, cost of urea, and cost of water supply were significant at the $1 \%$ significance level. In order to enhance the productivity of pomegranate farming in Kandahar province, it is recommended that the government and other agricultural organizations should support farmers so 
that they can cope with the costs of those factors which were found to have a significant impact on the production or growth of pomegranates in the province. Furthermore, the $\mathrm{R}^{2}$ value in the results of the study suggests that pomegranate production is highly dependent on other factors not investigated in this study. These could include land size, quality of chemicals, and the use of technology. Therefore, it is recommended that other studies should analyze these factors more thoroughly.

\section{References}

Brown, D. 2008. Afghanistan Markets its Pomegranates.

https://www.sandiegouniontribune.com/sdut-afghan-pomegranates-not-poppies-1120082008nov20-story.html (Retrieved Sep 2019).

Dawrani, Noor Ahmed. 2010. Afghanistan Investment Support Agency. http://investinafghanistan.af/about-aisa/ (Retrieved Sep 2019).

Kamble, B.H. 2004. Economics of production and marketing of pomegranate of Sangli district. Indian Journal Agricultural Economics, 7(2):52-56.

Kandahar Chamber of Commerce. 2015. http://www.acci.org.af/ (Retrieved Sep 2019)

Nagesh, S. 2008. Study on entrepreneurial behaviour of pomegranate growers in Bagalkot district of Karnataka. M.Sc. (Agri.) Thesis, University of Agricultural Sciences, Dharwad. Pajhwok Report. 2018. https://www.pajhwok.com/en/2018/10/29/kandahar-produces-150000tons-pomegranates (Retrieved Oct 2019)

Patil, S.M. 1995. Yield gaps and constraints in groundnut production in Karnataka: An economic Analysis. M.Sc. (Agri.) Thesis, University of Agricultural Sciences, Dharwad.

Sadiq Mustafa. 2010. Major deal signed to buy pomegranate juice from Afghanistan, Published in Afghan News Journal.

Statistical Yearbook. 2017. Afghanistan Central Statistical Organization. https://nsia.gov.af/choose-lang (Retrieved Nov 2019)

United States Department of Agriculture, Afghan Agriculture. https://afghanag.ucdavis.edu/ (Retrieved Nov 2019) 